\title{
Risk Factors and Management Problems in Non-Hemolytic Cholelithiasis in Children
}

\author{
Non-Hemolitik Kolelitiazisli Çocuklarda Risk Faktörleri ve Yönetim Sorunları
}

Didem Baskın Embleton ${ }^{1}$, Ayşegül Bükülmez ${ }^{2}$, Sezgin Yılmaz ${ }^{3}$, Ahmet Ali Tuncer ${ }^{1}$, Salih Çetinkurşun ${ }^{1}$

\begin{abstract}
${ }^{1}$ Afyon Kocatepe University, Faculty of Medicine, Department of Pediatric Surgery, Afyonkarahisar, Turkey
${ }^{2}$ Afyon Kocatepe University, Faculty of Medicine, Department of Pediatrics, Afyonkarahisar, Turkey

${ }^{3}$ Afyon Kocatepe University, Faculty of Medicine, Department of General Surgery, Afyonkarahisar, Turkey
\end{abstract}

\section{ABSTRACT}

Objective: Present study has been conducted to evaluate the management of non-hemolytic cholelithiasis in children in a single center.

Methods: Children with non-hemolytic cholelithiasis between 2011 and 2016 were included in the study. Age, sex, risk factors, additional pathologies, symptoms at admittance, type of treatment given and results were examined retrospectively.

Results: Forty-four patients were included. Mean age was 9.31years. There were 19 male and 25 female patients. All patients admitted with abdominal pain and the diagnosis was made with ultrasonography. Risk factors/additional pathologies were as follows: previous surgery $(n=6)$, previous antibiotic usage $(n=5)$, cerebral palsy $(n=1)$, Down syndrome $(n=2)$, heart disease $(n=2)$, Henoch-Schöenlein purpura $(n=1)$, pancreatitis $(n=1)$, obesity $(n=2)$ and history of familial gall bladder stones $(n=3)$. Seventy eight percent of the risk factors involved prior hospitalization and intravenous antibiotic usage.

In younger patients and patients with risk factors, oral ursodeoxycholic acid (UDCA) $10 \mathrm{mg} / \mathrm{kg}$ twice daily was used. UDCA treatment was effective in $37.5 \%$ of the patients.

Ten patients had cholecystectomy. They were older than 10 years. Chronic cholecystitis was present in all cholecystectomy specimens. After cholecystectomy, three patients still have intermittent abdominal pain and one has diarrhea attacks.

Conclusion: In patients that needed hospitalization and IV antibiotic use for other reasons, screeningfor the gall bladder stones may lead to early use of UDCA and dissolution of the stones.For parents and surgeons, the most comfortable age in children for cholecystectomy for persistent gall stones seems the age older than 10 years in our series.

Key Words: Cholelithiasis, cholecystectomy, ursodeoxycholic acid, child

\section{ÖZET}

Amaç: Çalışmamız, tek bir merkezde, non-hemolitik kolelitiyazisi olan çocuklardaki yaklaşımlarınızı değerlendirmek amacıyla yapılmışıı.

Gereç ve Yöntemler: Çocuk cerrahisi departmanında 2011-2016 yılları arasında izlenmiş olan non-hemolitik kolelitiyazisli çocuklar çalışmaya dahil edildi. Yaş, cinsiyet, risk faktörleri, ek patolojiler, başvuru semptomları, verilen tedavi ve sonuçlar retrospektif olarak değerlendirildi.

Bulgular: Toplam 44 hasta incelendi. Ortalama yaş 9.31 yıl bulundu. Ondokuz erkek, 25 kız hasta vardı. Tüm hastalar karın ağrısı ile başvurdular ve tanı ultrasonografi (US) ile koyuldu. US ile spesifik kolesistit bulguları görülmedi.Risk faktörleri/ek hastalıklar geçirilmiş cerrahi (6), antibiyotik kullanmış olma $(n=5)$, serebral palsi $(n=1)$, Down sendromu $(n=2)$, kalp hastalı̆ı $(n=2)$, Henoch-Schöenlein purpurası $(n=1)$, pankreatit $(n=1)$, obesite $(n=2)$ ve ailede safra taşı öyküsü olması $(n=3)$ olarak saptandı. Risk faktörlerinin \%78'ieski hastane yatışı ve intravenöz antibiyotik kullanımı ile ilişkiliydi. Küçük yaştaki hastalarda ve risk faktörü olanlarda $10 \mathrm{mg} / \mathrm{kg}$ ursodeoksikolik asit (UDKA) günde 2 kez olarak başlandı. UDKA tedavisi ilacı kullanan hastaların $\% 37.5$ 'inde etkili oldu. On hastaya kolesistektomi yapıldı. Hepsi 10 yaşından büyüktü. Tüm kolesistektomi materyallerinde kronik kolesistit vardı.Kolesistektomi sonrası 3 hastada karın ağrısı devam etti, bir hastada aralıklı ishal atakları oldu.

Sonuç: Başka nedenlerle hastane yatışı ve IV antibiyotik kullanımı gereken hastalarda safra taşıtaramaları, UDKA'nın erken kullanımını ve dolayısıyla taşların erimesini sağlayabilir. Sebat eden taş varlığında, kolesistektominin aileler ve cerrahlar tarafından rahat kabul edildiği yaş, komplikasyon yokluğunda 10 yaş ve üzeri gibi görünmektedir.

Anahtar Sözcükler: Kolelitiyazis, kolesistektomi, ursodeoksikolik asit, çocuk

Geliş Tarihi: 25.01.2017

Kabul Tarihi: 27.02.2017 


\section{INTRODUCTION}

Cholelithiasis has been increasingly diagnosed in children after the widespread use of ultrasonography (US). Risk factors for childhood cholelithiasis include hemolytic diseases, gastrointestinal problems (Crohn's disease, intestinal resections), hepatobiliary system disorders (biliary malformations, Wilson's disease), cystic fibrosis, sepsis, total parenteral nutrition, antibiotic usage such as ceftriaxone, and obesity $(1,2)$. In the recent years, there seems to be an increased incidence in cholelithiasis cases without any of these risk factors. Although the offered treatment is cholecystectomy in the presence of acute cholecystitis symptoms, and observation if there are no symptoms, especially in younger children, there seems to be other presentations of cholecystitis that are in between these two clinical types. To determine the disease progress and treatment choices, a retrospective evaluation of patients with cholelithiasis was planned, excluding the hemolytic cases of cholelithiasis.

\section{METHODS}

Children with symptomatic cholelithiasis that were seen between 2011 and 2016 in a pediatric surgery unit were included in the series after the hemolytic causes were excluded. Retrospective evaluation of age, gender, additional pathologies, risk factors for cholelithiasis, initial symptoms, and laboratory findings was made. Patients were also evaluated in 2 groups according to the treatment they received: non-operative management group and operative management group.

The Clinical research ethics committee of Kutahya Dumlupınar University (2015-KAEK-86/09-168) approved the study and written informed consent was received from patients' parents.

\section{Statistical evaluation}

Mann Whitney $U$ test was used to look for any difference in ages comparing the gender and cholecystectomy status.

\section{RESULTS}

Forty-four patients were included (Table 1). Mean age was 9.31years (1-18 years). There were 19 male (45.45\%) and 25 female patients $(54.55 \%)$.

Table 1. Characteristics of the children with non-hemolytic cholelithiasis

Age 1-18 years (mean 9.31 years)

In operated children $10-18$ years (mean 13.3 years)

In non-operative management group 1-16 years (mean 8.24 years)

Male/female 19/25

In operated children $5 / 5$

In non-operative management group 15/19

Risk factors $(n=23)$ :

Previous surgery 6

Previous IV antibiotic usage in another center 5

Cerebral palsy 1

Down syndrome 2

Familial history of gall stone disease 3

Obesity 2

Mitral valve insufficiency 1

Ventricular septal defect 1

Henoch-Schöenlein purpura 1

Pancreatitis 1

Liver function tests* Abnormal/Normal 7/38

White blood count** High/Normal 3/42

CRP*** High/Normal 3/30

USG findings:

Mud 6

Only gall bladder stones 39

Additional inflammatory findings 1 (pericholecystic fluid)

Hospitalization during attacks 7 patients ( 2 in the operative group, 5 in the non-operative management group)

*Liver function tests include ALT (0-34 U/L), AST (0-49 U/L) and GGT (11-49 $\mathrm{U} / \mathrm{L}$ ). If any one of them was above the normal limits, the test was considered as abnormal.

$* *$ White blood count $\left(4.0-10.0 \times 10^{3} / \mathrm{uL}\right)$

$* * *$ CRP $(0-0.8 \mathrm{mg} / \mathrm{dL}$ ) was evaluated in 33 patients.
Risk factors and/or additional pathologies

Previous surgery $(n=6)$, previous antibiotic usage in another center $(n=5)$ cerebral palsy $(n=1)$, Down syndrome $(n=2)$, heart disease $(n=2)$, HenochSchöenlein purpura $(n=1)$, pancreatitis $(n=1)$, obesity $(n=2)$ and history of familial gall bladder stones $(n=3)$ were detected as risk factors. Previous surgeries were appendectomy in four, laparotomy for hydatid cyst in one and orchidopexy in one.

The patients with cerebral palsy, Down syndrome, heart disease, HenochSchöenlein purpura and pancreatitis were all hospitalized for infection and had IV antibiotic treatment. The gall bladder stones appeared after the antibiotic treatment.

Body-mass index could be and calculated in 18 patients (40.9\%), it was lower than 25 in 16, and it was lower than 18.5 in 11 of the 16 patients. Two patients had a body mass index over 30 .

Diagnostic evaluations

All patients came with abdominal pain and diagnosis was made with ultrasonography (US) in all. US did not reveal any signs of cholecystitis other than stones $(n=35)$ or mud $(n=9)$ in the gall bladder except in one patient that additionally had minimal fluid accumulation around the gall bladder. Magnetic resonance imaging (MRI) was used if choledocholithiasis was suspected.

Liver function tests including AST, ALT and GGT were abnormal in seven patients (15.9\%). White blood count was high in three patients (6.8\%). CRP was normal in 30 patients, high in three patients $(9.0 \%)$ and this test was not performed in the others.

Only seven patients (15.9\%) were hospitalized for acute cholecystitis attack and had classical treatment. Rest of the patients had oral antibiotics and followed in outpatient clinics.

\section{Non-operative management group $(n=34)$}

In younger patients that has non-specific abdominal pain and in patients with risk factors or additional illnesses, oral antibiotics were given, and they were called for repeat US. Their mean age was 8.24 years. If there was a persistent stone, but no abdominal pain or any other symptom, oral ursodeoxycholic acid (UDCA) $10 \mathrm{mg} / \mathrm{kg}$ twice daily was started. Follow-up was performed with monthly US. UDCA was stopped in patients that showed no regression in stone size after 6 months.

Follow-up was 1 month to 3 years. UDCA was used properly in 24 children. Stones or mud disappeared in 15 children, nine children were using UDCA and six patients needed no treatment. The patients with the history of antibiotic usage were among the ones that the stones had disappeared. There was no difference in size or number of stones in 17 patients. Abdominal pain persisted in six patients that had UDCA treatment. Of these, two later had cholecystectomy due to the persistence of their symptoms.

\section{Operative management group $(n=10)$}

Ten patients had open $(n=4)$ or laparoscopic $(n=6)$ cholecystectomy after the initial acute attack. Mean age was 13.30 years. Cholecystectomy was performed in 15 days to 3 years after the initial diagnosis. Three patients with previous surgery were in this group. A17-year-old patient had a cholecystectomy during appendicitis operation. One patient that was initially diagnosed in another center 3 years ago, came with an acute cholecystitis attack, and operation was performed. Another 2 developed cholecystitis attack during their follow-up and operated.

Pathological examination of the gall bladder revealed chronic cholecystitis in all patients. Stone examination was not made. There were no early postoperative complications except a pericecal intra-abdominal abscess due to a fallen fecalith in the patient that had appendectomy and simultaneous cholecystectomy. During the follow-up of cholecystectomy patients, abdominal pain continued in three patients and one patient had multiple diarrhea attacks. There was no mortality in the series.

\section{Statistical evaluation}

Mann Whitney $U$ test was used to look for any difference in ages comparing the gender and cholecystectomy status. Mean age was 9.48 years in boys and 9.26 years in girls. There was no statistical difference between ages $(p=0.915)$. Mean age was 13.30 years in the cholecystectomy group, and 8.24 years in the non-cholecystectomy group. This difference was statistically important $(p=0.001)$. 


\section{DISCUSSION}

The age difference comparing boys and girls was not statistically important in the series. The number of boys was nearly equal to the number of girls. In Iran series there were more boys but sex ratio was equal in Italian series (1, 2).

Obesity was $4.5 \%$ in the series, and it was higher than Iran series, which was $2 \%$, but closer to the percentage reported from central Anatolia (3). When body mass index was calculated in 18 children, surprisingly it was found that $61.1 \%$ of the children has an index lower than 18.5 . This is opposite to the findings of a Korean study (4). It is probably due to higher hospitalization rate of the group for reasons other than gall bladder stones.

Other risk factors such as previous surgery, antibiotic usage, and positive family history were also seen in the series $(1,2)$. Additional pathologies such as Down's syndrome, cerebral palsy, Henoch-Schöenlin purpura, pancreatitis, and congenital heart disease required hospitalizations and antibiotic usage that was prior to the diagnosis of cholelithiasis in our series. These factors can also be evaluated in the same category with the prior antibiotic usage. Patients with either acute or chronic conditions that need frequent and/or long term antibiotic usage may have an additional risk for developing gall bladder stones.

Classical presentation of cholecystitis was present in only three patients. There was upper abdominal pain in the rest but there was no fever, blood tests were mostly normal, and US findings revealed only the presence of stones. Ultrasonography is the preferred method for the diagnosis of gall bladder stones. It is non-invasive, cheap and it has a high sensitivity of $82 \%$ for cholelithiasis (5). It can also be used for follow-up of the mud and stones. If there are additional pathologies such as pancreatitis, or findings of obstructive jaundice, other imaging techniques such as magnetic resonance imaging will be added to determine the anatomical problems. But ultrasonographical findings even during cholecystitis attacks have lower sensitivity and positive predictive values for cholecystitis in children compared to adults (5). Although all patients admitted with abdominal pain, a group of patients became asymptomatic with oral antibiotic treatment only. The mean age of this group that has non-specific abdominal pain is 8.24 years and it is younger than the operated group (mean age 13.3 years) and this finding is statistically important. Looking at some other large series of cholecystectomy, operative median age in children is older than 13 years $(6,7)$ except one series that operated all children even if they were asymptomatic with a median age of 11 years (8). Youngest patient that was operated was ten years old in our series. Neither laboratory tests nor US findings were as helpful as the clinical findings including abdominal pain and vomiting for decision of cholecystectomy in our experience. Risk factors were also not helpful.

Disappearance of gall stones was $37.5 \%$ with oral UDCA use in our series. Similar results were encountered in other series $(2,3)$. UDCA is a bile acid. It is being used especially to dissolve cholesterol stones. It is not useful in pigment stones (9). If UDCA is effective, the size of the stone decreases $1 \mathrm{~mm}$ each month (10). We did not see this affect in our series. Some papers propose that, although UDCA does not have any effect on stones, it helps to decrease the symptoms by its anti-inflammatory effect $(2,9)$. Abdominal pain persisted in $25 \%$ of the patients receiving UDCA in our series. Two patients had cholecystectomy because of recurrent abdominal pain while using UDCA during their follow-up.

Gall stones due to antibiotic usage usually disappear after discontinuation of antibiotics according to literature (11). In this series, the gall stones developed after antibiotic usage were millimetric in size, or was as mud, and they disappeared after discontinuation of antibiotics mostly within a few months, which was verified with follow-up ultrasonographies. UDCA seems to be effective in such patients in our experience, but the numbers are small for efficient statistical evaluation.

There were no choledochal obstructions in the series, which is one of the risks of conservative treatment.

Cholecystectomy was performed in $22.2 \%$ of the patients. The decision was faster in the patients that had previous abdominal surgeries. The main reason for operation in these patients was to rule out adhesive intestinal obstruction. Although classically centers offer cholecystectomy for cholecystitis symptoms, some centers try medical treatment first (2). We also did not offer immediate cholecystectomy in young children if their symptoms had disappeared after antibiotic therapy. Cholecystotomy was tried in one series (9). Recurrences have been reported after medical treatment or cholecystotomy (9). We do not have recurrences in our series.

Pathological evaluation of the gall bladder revealed chronic cholecystitis in all our cholecystectomy patients as expected (5). This should be a concern when following a child with gallstones for a long period.
Not many studies have been done about the functional results of cholecystectomy in children. Postcholecystectomy syndrome has been reported as $4.7 \%$ in one series (2). Abdominal pain persisted in three of the ten cholecystectomy patients, and one patient had diarrhea attacks after cholecystectomy in the our series.

As a result, in this series, nearly half of the children with gall bladder stones or mud had prior IV antibiotic use due to various reasons. In such patients, screening for a gall bladder stone before it gets bigger or while it is in the shape of mud and early administration of UDCA may result in dissolution of the stones. In case of persisting gallstones, cholecystectomy age that both surgeons and families are comfortable with seems like the age older than 10 years.

\section{Conflict of interest}

No conflict of interest was declared by the authors.

\section{REFERENCES}

1. Dooki MRE, Norouzi A. Cholelithiasis in childhood: A cohort study in North of Iran. Iran J Pediatr 2013; 23: 588-92.

2. Della Corte Ci Falchetti D, Nebbia G, Calacocci M, Pastore M, Francavilla R, Marcellini $\mathrm{M}$, et al. Management of cholelithiasis in Italian children: a national multicenter study. World J Gastroenterol 2008; 14: 1383-8.

3. Gökçe $S$, Yıldırım M, Erdoğan D. A retrospective review of children with gallstone: Single-center experience from Central Anatolia. Turk J Gastroenterol 2014; 25: 46-53.

4. Kin HY, Kim SH, Cho YH. Pediatric cholecystectomy: Clinical significance of cases unrelated to hematologic disorders. Pediatr Gastroenterol Hepatol Nutr 2015; 18: 115-20.

5. Tsai J, Sulkowski JP, Cooper JN, Mattei P, Deans KJ, Minneci PC. Sensitivity and predictive value of ultrasound in pediatric cholecystitis. J Surgica Research 2013; 184: 378-82.

6. Langballe KO, Bardram L. Cholecystectomy in Danish children. J Ped Surg 2014; 49: 626-30.

7. Campbell S, Richardson B, Mishra P, Wong M, Samarakkody U, Beasley S, et al. Childhood cholecystectomy in New Zealand: A multicenter national 10 year perspective. J Pediatr Surg. 2016;51:264-7.

8. Tannuri ACA, Leal AJG, Velhote MCP, Gonlçalves MEP, Tannuri U. Management of gallstone disease in children: A new protocol based on the experience of a single center. J Pediatr Surg 2012; 47: 2033-8.

9. Stevensson J, Makin E. Gallstone disease in children. Seminars in Ped Surg 2012; 21: 255-65.

10. Guarino MPL, Cocca S, Altomare A, Emerenziani S, Cicala M. Ursodeoxycholic acid therapy in gallbladder disease, a story not yet completed. World J Gastroenterol 2013; 19: 5029-34.

11. Rodriguez Rangel DA, Pinilla Orajenera AP, Bustacara Diaz M, Henao Garcia $\mathrm{N}$, Lopez Cadena A, Montoya Camargo R, et al. Gallstones in association with the use of ceftriaxone in children. An Pediatr (Barc) 2014; 80: 77-80. 